\title{
Analisis Faktor-Faktor Yang Mempengaruhi Kualitas Pelaksanaan Pengadaan Barang/Jasa Di Pemerintah Provinsi Gorontalo
}

\author{
SURYA H. AHMAD ${ }^{1}$, JULLIE J. SONDAKH ${ }^{2}$, JENNY MORASA ${ }^{3}$ \\ ${ }^{1,2,3}$ Program Studi Magister Akuntansi, Fakultas Ekonomi dan Bisnis Universitas Sam Ratulangi \\ email : surya.ahmad8501@gmail.com ${ }^{1}$,julliesondakh@yohoo.com², jennymorasa@ hotmail.com ${ }^{3}$
}

\begin{abstract}
Procurement of government goods / services is the activity of obtaining goods / services at reasonable prices, quantity and quality appropriately and timely. Goods / services procurement activities cover efforts to meet the needs of goods / services based on prevailing regulations and legislation, with various considerations for the purposes of easy control and evaluation. By implementating good procurement of goods / services, the good governance atmosphere is hoped to be established. This study aims to analyze the factors that affect the quality of procurement of goods / services in the Provincial Government of Gorontalo. This is a quantitative research and data were analysed by multiple linear regression analysis. Primary data were employed in this study and collected by distributing questionnaires. This study uses four independent variables, namely selfestimate price (HPS), time of procurement of goods / services, integrity, method of selection of goods / service providers, and one dependent variable is the quality of procurement of goods / services.The result of the research shows that the estimated price affect negatively and significantly the quality of the procurement of goods / services. On the other hand, the time of procurement of goods / services, integrity, and the method of selection of goods / service providers affect positively and significantly the quality of procurement of goods / services in the Government Gorontalo Province.
\end{abstract}

Keywords: HPS, Implementation of procurement of goods / services period, integrity, procurement of goods/services.

\begin{abstract}
Abstrak. Pengadaan barang/jasa pemerintah merupakan kegiatan memperoleh barang/jasa dengan harga yang dapat dipertanggungjawabkan, jumlah dan kualitas yang sesuai serta pengadaan yang tepat waktu. Kegiatan pengadaan barag/jasa mencakup usaha-usaha untuk mencukupi kebutuhan barang/jasa berdasarkan peraturan dan perundang-undangan yang berlaku, dengan berbagai pertimbangan agar pengendalian dan evaluasi mudah dilakukan. Dengan pelaksanaan pengadaan barang/jasa yang baik akan menciptakan suasana pemerintahan yang baik (Good Governance). Penelitian ini bertujuan untuk menganalisis faktor-faktor yang mempengaruhi kualitas pelaksanaan pengadaan barang/jasa di Pemerintah Provinsi Gorontalo. Metode penelitian yang digunakan adalah metode kuantitatif dengan analisis regresi linear berganda. Sumber data yang digunakan dalam penelitian ini adalah data primer dan pengumpulan data dilakukan secara langsung dengan menggunakan kuesioner. Penelitian ini menggunakan empat variabel independen yaitu harga perkiraan sendiri (HPS), waktu pelaksanaan pengadaan barang/jasa, integritas, metode pemilihan penyedia barang/jasa, dan satu variabel dependen yaitu kualitas pelaksanaan pengadaan barang/jasa.Hasil penelitian menunjukan bahwa harga perkiraan memiliki pengaruh negatif dan signifikan terhadap kualitas pelaksanaan pengadaan barang/jasa, sedangkan waktu pelaksanaan pengadaan barang/jasa, integritas, dan metode pemilihan penyedia barang/jasa memiliki pengaruh positif dan signifikan terhadap kualitas pelaksanaan pengadaan barang/jasa di Pemerintah Provinsi Gorontalo.
\end{abstract}

Kata Kunci: HPS, waktu pelaksanaan pengadaan barang/jasa, integritas, pengadaan barang/jasa.

\section{Pendahuluan}

Pada dasarnya pengadaan barang/jasa adalah upaya pihak pengguna untuk mendapatkan atau mewujudkan barang/jasa yang diinginkannya, dengan menggunakan metode dan proses tertentu agar dicapai kesepakatan harga, waktu, dan kesepakatan lainnya. Agar hakekat atau esensi pengadaan barang/jasa tersebut dapat dilaksanakan sebaik-baiknya, maka kedua belah pihak yaitu pihak pengguna dan penyedia haruslah selalu berpatokan kepada filosofi pengadaan barang/jasa, tunduk kepada kepada etika dan norma pengadaan barang/jasa yang baku. Proses pengadaan barang/jasa di Indonesia diatur dalam Peraturan Presiden Nomor 54 Tahun 2010 tentang pengadaan barang/jasa pemerintah.

Penjelasan peraturan Presiden Nomor 54 tahun 2010 tentang pengadaan barang/jasa pemerintah menyatakan bahwa tata pemerintahan yang baik dan bersih (Good Governance and Clean Government) adalah seluruh aspek yang terkait dengan kontrol dan pengawasan terhadap kekuasaan yang dimiliki pemerintah dalam menjalankan fungsinya melalui institusi formal dan informal. Pelaksanaan prinsip Good Governance and Clean Goverment dilakukan melalui penerapan prinsip- 
prinsip akuntabilitas dan pengelolaan sumber daya secara efisien, serta mewujudkannya dengan tindakan dan peraturan yang baik dan tidak berpihak (independen), serta menjamin terjadinya interaksi ekonomi dan sosial antara para pihak terkait (stakeholders) secara adil, transparan, profesional, dan akuntabel.

Usaha dalam rangka mencapai tujuan tersedianya output barang atau jasa yang berkualitas, pengaturan pengadaan barang/jasa terus menerus diperbaiki. Perbaikan menyeluruh dari aspek regulasi, pelayanan dan kelembagaan. Pertama, perbaikan dari sisi regulasi, sejak tahun 2000 pemerintah telah mengeluarkan aturan khusus tentang pengadaan barang/jasa. Aturan khusus itu adalah Keputusan Presiden Nomor 18 Tahun 2000 yang bertujuan mengatur pengadaan barang/jasa agar tercapai prinsip-prinsip pengadaan barang/jasa yaitu persaingan sehat, transparan, terbuka dan perlakuan yang adil bagi semua pihak, sehingga hasilnya dapat dipertanggungjawabkan baik dari segi fisik, keuangan maupun manfaat bagi kelancaran tugas pemerintah dan pelayanan masyarakat. Saat ini prinsip pengadaan barang/jasa pemerintah di Indonesia mengedepankan 7 prinsip yaitu efisien, efektif, transparan, terbuka, bersaing, adil/tidak diskriminatif dan akuntabel.

Badan Pemeriksa Keuangan (BPK) dalam hasil pemeriksaan Semester II tahun 2016 dengan objek pemeriksaan pengelolaan dan pertanggungjawaban belanja operasional TA 2016 (s.d 31 oktober 2016) di Pemerintah Provinsi Gorontalo berkaitan dengan ketidakpatuhan terhadap ketentuan peraturan perundang-undangan, telah terjadi permasalahan pada indikator ketidakpatuhan sebanyak 16 kasus dengan nilai Rp. 822,69 juta. indikator kekurangan volume pekerjaan barang sebanyak 1 kasus dengan nilai Rp. 11.98 juta. Indikator kelebihan pembayaran pekerjaan, namum belum dilakukan pelunasan pembayaran pada rekanan 1 kasus dengan nilai Rp. 30,79 juta. Indikator penerimaan selain denda keterlambatan belum dipungut/diterima 2 kasus dengan nilai Rp. 122,42 juta. Indikator permasalahan ketidak patuhan lain-lain sebanyak 12 kasus dengan nilai Rp. 657,50 juta.

Alfian (2015) mengatakan dalam sistim pengadaan, modus operandi yang sering dilakukan adalah (1) penetapan sistem pemilihan penyedia barang/jasa cenderung kepada penunjukkan langsung; (2) pemilihan sistem evaluasi penawaran mengarah kepada sistem yang mampu mengamankan penyedia dan anggaran termasuk unsur "suap" dan "uang terima kasih" yang telah ditetapkan; (3) kecenderungan pemilihan sistem kontrak jenis lump-sum untuk memudahkan melakukan praktek mark-up anggaran atau HPS.

Alfian (2015) juga menjelaskan pada tahap penyusunan jadwal modus operandi yang sering dilakukan adalah (1) alokasi waktu seperti pengumuman pelelangan dan pemasukan dokumen penawaran sangat tidak realistis; (2) penggunaan waktu libur atau diluar hari kerja sebagai kegiatan pelaksanaan lelang; (3) penetapan jadwal proses lelang yang secara disengaja mendekati akhir tahun anggaran, sehingga memungkinkan dilakukan penunjukan langsung. Hehamahua (2011) menyebutkan bahwa modus penyimpangan pengadaan barang/jasa pada tingkat panitia pengadaan adalah integritas yang lemah, proses pengadaan yang tidak transparan, panitia pengadaan yang memihak, panitia pengadaan yang tidak independen.

Metode Pemilihan Pengadaan Barang/jasa juga merupakan salah satu faktor yang memiliki pengaruh terhadap jalannya sistim pengadaan barang/jasa. Dalam hal ini bahwa metode yang akan diambil dalam suatu penyelenggaran pengadaan barang/jasa akan menjadi satu penilaian tersendiri terhadap para calon peserta yang ambil bagian dalam kegiatan pengadaan barang. Seringkali dalam pengambilan metode dalam pelaksanaan barang/jasa menjadi tolak ukur dalam pelaksanaan audit. Sesuai dengan Peraturan Presiden Nomor 54 tahun 2010 pasal 35 ayat (1), 41 ayat (1) dan 47 ayat (1), ULP/ pejabat pengadaan mempunyai tugas dan wewenang untuk menyusun dan menetapkan metode pemilihan penyedia barang/jasa.

Hehamahua (2011) mengemukakan terjadi konflik kepentingan dalam pengadaan barang/jasa terjadi dimana seorang Pegawai Negeri Sipil yang mendapat kekuasaan dan kewenangan berdasarkan peraturan perundang-undangan memiliki atau diduga memiliki kepentingan pribadi atas setiap penggunaan wewenang yang dimilikinya sehingga dapat mempengaruhi kualitas dan kinerja yang seharusnya.

Ogunsanmi (2013) dalam penelitiannya mengatakan bahwa indikator untuk pengadaan barang/jasa ada beberapa kriteria yaitu biaya, waktu, kualitas, karakteristik proyek dan faktor lingkungan eksternal yang dapat mempengaruhi pada kinerja suatu pekerjaan proyek. Persaingan terbuka dan metode dalam pelaksanaan tender sangat berpengaruh terhadap kinerja proyek. Begitu juga Larasati (2011) Sebagai akibat kurangnya pemahaman terhadap risiko dan permasalahan di 
lapangan banyak terjadi perubahan pekerjaan (change order), adendum berulang kali dan pada akhirnya menyebabkan kinerja proyek buruk dalam hal waktu dan biaya. Berdasarkan teori dan penelitian terdahulu faktor-faktor yang dapat mempengaruhi kualitas pelaksanaan pengadaan barang/jasa antara lain penetapan harga perkiraan sendiri, waktu pelaksanaan pengaaan barang/jasa, integritas dan metode pemilihan penyedia pengadaan barang/jasa.

True (1988) mengindikasikan bahwa estimasi biaya pelaksanaan proyek yang diajukan sebagai penawaran biaya oleh para calon kontraktor di Amerika Serikat memiliki tingkat akurasi yang sangat bervariasi, baik pada proyek-proyek besar maupun kecil. Dibandingkan dengan estimasi biaya pengguna jasa, lebih dari 56\% penawaran biaya ternyata lebih rendah, dan bervariasi antara 5\% sampai $37 \%$ lebih rendah. Sedangkan penawaran di atas estimasi biaya pengguna jasa bervariasi antara $1 \%$ sampai $40 \%$ lebih tinggi. Meninjau estimasi biaya di antara para penawar sendiri, penawaran tertinggi seringkali besarnya dua kali lipat dari penawaran terendah.

Pich, Loch and Meyer (2002: 1009-1012) dengan perencanaan dan penjadwalan yang terencana dengan baik seorang meneger mampu menganalisa 'critical path' atau bagian dari proyek yang sangat besar pengaruhnya apabila tidak terlaksana dan akan mengakibatkan delay atau menghambat proses yang lain yang belum dilaksanakan dan memiliki dependensi yang sangat besar dengan proses kegiatan yang lain dan apabila seorang manager memiliki perencanaan dan penjadwalan yang tepat maka resiko yang diakibatkan bisa diatasi secara cepat.

Untuk mencegah dan tidak melakukan kolusi, korupsi, dan nepotisme (KKN) dalam pelaksanaan barang/jasa, pemerintah menerapkan suatu tindakan berupa pernyataan yang tertuang dalam fakta integritas yang dikemukakan pada pasal 1 angka 13 Peraturan Presiden Nomor 54 Tahun 2010 yaitu surat pernyataan yang berisi ikrar untuk mencegah dan tidak melakukan kolusi, korupsi, dan nepotisme dalam pengadaan barang/jasa. Schlenker, Miller dan Johnson (2009) menyatakan bahwa derajat kejujuran individu bisa berbeda apabila dihadapkan pada kelompok individu yang berbeda, tergantung tujuan ingin menampilkan diri seperti apa (self-presentational goal). Namun hal itu tidak terjadi pada individu yang memiliki integritas tinggi, karena ia merasa tidak memiliki kepentingan apapun (contohnya ingin dipuji) dan hanya melakukan sesuatu yang benar berdasarkan standar dan batasannya sendiri.

Metode pemilihan adalah tata cara pemilihan calon penyedia dengan mengikuti tahapan tertentu untuk mendapatkan penawaran yang sesuai dengan kebutuhan pengguna akhir barang/jasa (LKPP, 2016). Jatiningtyas dan Endang (2011) menyatakan bahwa satu faktor yang mempengaruhi keberhasilan sistem pengadaan barang/jasa adalah profesionalisme atau kualitas penyedia barang/jasa. Menurut Beth (2005) dalam pemilihan pelaksana proyek itu sendiripun ada aturan yang harus diberlakukan agar memperlihatkan transparansi hasil penentuan siapa yang berhak untuk melaksanakan tender proyek pengadaan barang/jasa dari pemerintah.

\section{Metode Penelitian}

Metode penelitian yang digunakan adalah metode kuantitatif yang bertujuan untuk menganalisis dan mendapatkan bukti empiris pengaruh harga perkiraan sendiri $\left(\mathrm{X}_{1}\right)$, waktu pelaksanaan pengadaan barang/jasa $\left(\mathrm{X}_{2}\right)$, integritas $\left(\mathrm{X}_{4}\right)$, metode pemilihan penyedia pengadaan barang/jasa $\left(\mathrm{X}_{5}\right)$ sebagai variabel independen terhadap kualitas pelaksanaan pengadaan barang/jasa (Y) sebagai variabel dependen. Dengan teknik analisis regresi linear berganda.

Populasi yang digunakan dalam penelitian ini yaitu Satuan Kerja Perangkat Daerah (SKPD) yang berada di lingkungan Pemerintah Provinsi Gorontalo. Populasi dalam penelitian ini adalah Kuasa Pengguna Anggaran (KPA), Pejabat Pelaksana Teknis Kegiatan dan Pokja/Pejabat Pengadaan barang/jasa sebanyak 577 orang yang berasal dari 25 (dua puluh lima) SKPD di Pemerintah Provinsi Gorontalo.

Dari populasi yang ada di ambil sampel dengan cara purposive sampling. Purposive sampling adalah penyampelan dengan kriteria berupa suatu pertimbangan tertentu (Sugiyono, 2013) yang digunakan karena informasi yang akan diambil berasal dari sumber yang sengaja dipilih berdasarkan kriteria yang telah ditetapkan peneliti. Sampel dipilih berdasarkan kriteria tertentu sehingga dapat mendukung penelitian ini. Kriteria sampel yang digunakan dalam penelitian ini yaitu Kuasa Pengguna Anggaran (KPA), Pejabat Pelaksana Teknis Kegiatan (PPTK) dan pokja/pejabat pengadaan. Dari populasi yang ada akan diambil sejumlah sampel dengan menggunakan rumus Slovin. Sehingga 
sampel yang diperoleh sejumlah 85 orang tersebar pada P2LP dan 25 SKPD di Pemerintah Provinsi Gorontalo.

Harga perkiraan sendiri diukur dengan indikator penyusunan HPS, dan komponen HPS dengan menggunakan 9 (sembilan) pertanyaan. Waktu pelaksanaan pengadaan barang/jasa diukur dengan indikator pelaksanaan pelelangan, waktu/durasi pelaksanaan kegiatan, masa kontrak, penerbitan SPMK dengan menggunakan 9 (sembilan) pertanyaan. Integritas diukur dengan indikator kejujuran pokja/pejabat pengadaan, keberanian pokja/pejabat pengadaan, tanggungjawab pokja/pejabat pengadaan, ketaatan terhadap peraturan dengan menggunakan 8 (delapan) pertanyaan. Metode pemilihan penyedia barang/jasa diukur dengan indikator jenis pekerjaan, besaran pagu, resiko pekerjaan dengan menggunakan 9 (sembilan pertanyaan). Masing-masing item pertanyaan dalam setiap variabel diukur dengan skala Likert $1-5$ yang berarti $1=$ sangat tidak setuju sampai dengan $5=$ sangat setuju.

\section{Hasil dan Pembahasan}

Pengujian validitas dalam penelitian ini menggunakan Uji Confirmatory Factor Analysis. Jika korelasinya lebih besar dari 0,3 maka pernyataan yang dibuat dikatakan valid (Setiaji, 2004:59). Sejalan dengan penjelasan di atas, Sugiono (2013) menjelaskan bahwa setiap pernyataan yang diberikan lebih besar dari skala 0,3 yakni alat ukur dalam pengukuran validitas berada $<0.3$ maka (tidak valid) dan apabila > 0.3 (valid). Hasil pengujian menunjukan bahwa setiap butir pertanyaan variabel harga perkiraan sendiri, waktu pelaksanaan pengadaan barang/jasa, integritas, metode pemilihan penyedia barang/jasa dan kualitas pelaksanaan pengadaan barang/jasa berada diatas atau lebih besar dari 0,3. Sehingga semua item pertanyaan setiap variabel dinyatakan valid.

Uji reliabilitas dilakukan dengan metode internal consistency. Kriteria yang digunakan dalam uji ini adalah One Shot, artinya satu kali pengukuran saja dan kemudian hasilnya dibandingkan dengan pertanyaan lainnya atau dengan kata lain mengukur korelasi antar jawaban pertanyaan. mengukur reliabilitas dengan uji statistik Cronbach Alpha ( $\alpha$ ). Jika nilai koefisien alpha $>0,60$ maka disimpulkan bahwa instrumen penelitian tersebut handal atau reliable (Ghozali, 2013). Hasil pengujian menunjukan bahwa untuk variabel harga perkiraan sendiri memiliki nilai 0,818 ; waktu pelaksanaan pengadaan barang/jasa memiliki nilai 0,792 ; integritas memiliki nilai 0,788 ; metode pemilihan penyedia barang/jasa memiliki nilai 0,771 ; dan kualitas pelaksanaan pengadaan barang/jasa memiliki nilai 0,872 . Dengan demikian pengukuran kuesioner ini dinyatakan reliable karena memiliki nilai Cronbach's Alpha diatas 0,60.

Uji normalitas dilakukan untuk mengetahui data berdistribusi normal. Uji normalitas data melalui uji Kolmogorov-Smirnov, nilai sginifikansi harus diatas $10 \%$ atau 0,10 . Hasil pengujian dengan banyaknya responden (n) sebesar 85 , menghasilkan nilai signifikansi untuk masing-masing variabel yakni harga perkiraan sendiri 0,449 , variabel waktu pelaksanaan pengadaan barang/jasa 0,192 , variabel integritas 0,127 , variabel metode pemilihan penyedia barang/jasa 0,627 dan kualitas pelaksanaan pengadaan barang/jasa 0,111 dengan nilai signifikansi masing-masing variabel masih lebih besar dari skala 0,10 yang menjelaskan bahwa data yang diolah telah terdistribusi secara normal sehingga asumsi normalitas penelitian ini telah tercapai.

Uji heterokedastisitas ditandai dengan adanya pola tertentu pada grafik scatterplot. Jika titiktitik yang ada membentuk suatu pola tertentu yang teratur (bergelombang), maka terjadi heteroskedastisitas. Jika tidak ada pola yang jelas, titik-titik menyebar di atas dan di bawah angka nol pada sumbu Y, maka tidak terjadi heteroskedastisitas. 


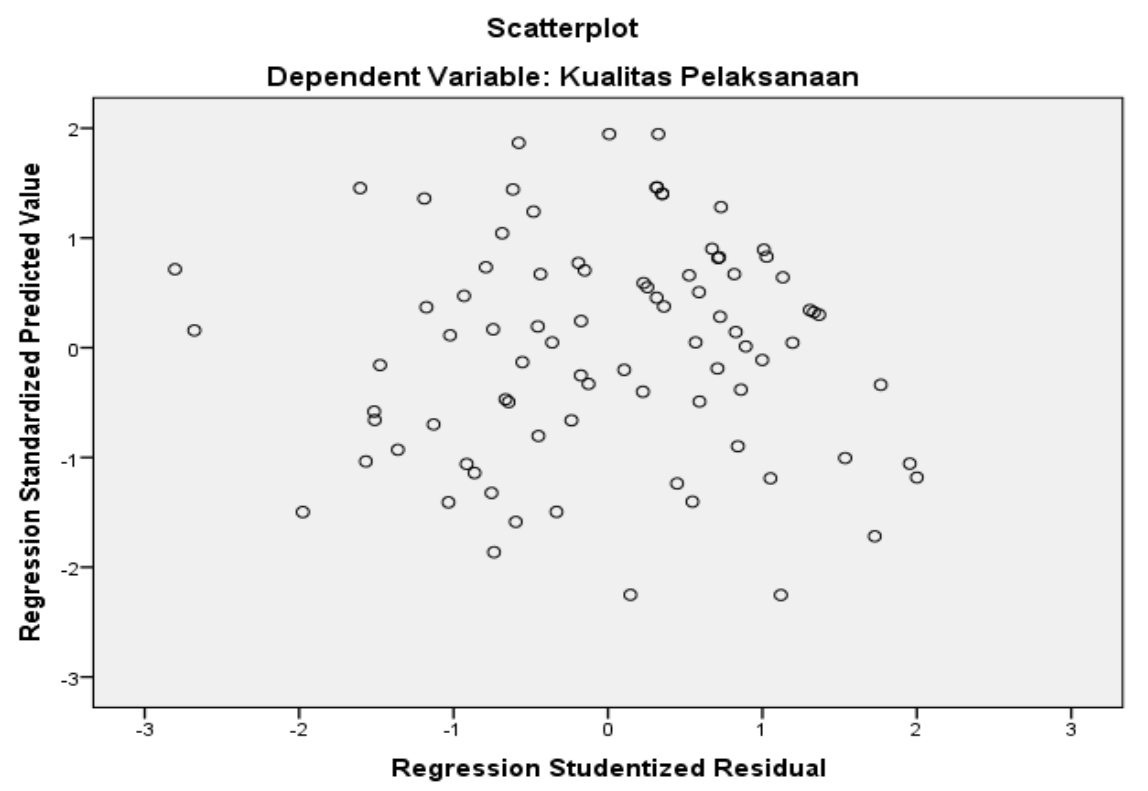

Pada scatterplot menunjukan bahwa titik-titik yang ada tidak membentuk sebuah pola namun menyebar. Sehingga dalam penelitian ini dapat disimpulkan bahwa penelitian ini tidak terjadi heterokedastisitas.

Hasil pengujian asumsi klasik menunjukan bahwa model regresi yang dipakai telah memenuhi asumsi klasik sehingga dapat dilanjutkan dengan analisis regresi berganda. Model regresi berganda dalam penelitian ini adalah untuk menguji pengaruh harga perkiraan sendiri $\left(\mathrm{X}_{1}\right)$, waktu pelaksanaan pengadaan barang/jasa $\left(\mathrm{X}_{2}\right)$, integritas $\left(\mathrm{X}_{3}\right)$, metode pemilihan penyedia barang/jasa $\left(\mathrm{X}_{4}\right)$, terhadap kualitas pelaksanaan pengadaan barang/jasa (Y).

\begin{tabular}{|l|r|r|r|r|r|}
\hline Model & \multicolumn{2}{|c|}{$\begin{array}{c}\text { Unstandardized } \\
\text { Coefficients }\end{array}$} & $\begin{array}{c}\text { Standardized } \\
\text { Coefficients }\end{array}$ & \multirow{2}{*}{ T } & \multirow{2}{*}{ Sig. } \\
\cline { 2 - 4 } & \multicolumn{1}{|c|}{ B } & Std. Error & \multicolumn{1}{c|}{ Beta } & & \\
\hline (Constant) & 20.451 & 6.002 & & 3.407 & .001 \\
HPS & -.208 & .111 & -.205 & -1.869 & .065 \\
Waktu Pelaksanaan & .176 & .100 & .176 & 1.756 & .083 \\
Integritas & .228 & .133 & .181 & 1.715 & .090 \\
Metode Pemilihan & .463 & .103 & .450 & 4.474 & .000 \\
\hline
\end{tabular}

Pengujian hipotesis dengan uji t dilakukan untuk mengetahui besarnya pengaruh masingmasing variabel independen secara individual terhadap variabel dependen. Uji juga dilakukan dengan membandingkan nilai $t_{\text {hitung }}$ dengan nilai $t_{\text {tabel }}$. nilai $t_{\text {hitung }}$ diperoleh dari hasil perhitungan SPSS, sedangkan nilai $t_{\text {tabel }}$ diperoleh dari tabel distribusi t dengan dicari pada $\alpha=10 \%: 2=5 \%(0,05)$ pada besarnya df (degree of freedom). Nilai df sebesar n-k-1 = 85-4-1 $=80$. Sehingga di peroleh nilai $\mathrm{t}_{\text {tabel }}$ sebesar 1,664.

Pengaruh harga perkiraan sendiri terhadap kualitas pelaksanaan pengadaan barang/jasa, diperoleh nilai $\mathrm{t}_{\text {hitung }}$ sebesar -1.869 dan nilai $\mathrm{t}_{\text {tabel }}$ sebesar 1,664 . Nilai signifikansi yang diperoleh sebesar $0,065<0,10$. Sesuai dengan penjelasan sebelumnya, maka dapat disimpulkan bahwa variabel hasil perkiraan sendiri memiliki pengaruh negatif dan signifikan terhadap kualitas pelaksanaan pengadaan barang/jasa, atau $\mathrm{H}_{\mathrm{a}}$ diterima dan $\mathrm{H}_{0}$ ditolak.

Pengaruh waktu pelaksanaan pengadaan barang dan jasa terhadap kualitas pelaksanaan pengadan barang/jasa, diperoleh nilai $t_{\text {hitung }}$ sebesar 1.756 dan nilai $t_{\text {tabel }}$ sebesar 1,664. Nilai signifikansi yang diperoleh sebesar $0,083<0,10$. Sesuai dengan penjelasan sebelumnya, maka dapat disimpulkan bahwa variabel waktu pelaksanaan pengadaan barang/jasa memiliki pengaruh positif dan signifikan terhadap kualitas pelaksanaan pengadaan barang/jasa, atau $\mathrm{H}_{0}$ ditolak dan Ha diterima. 
Pengaruh integritas terhadap kualitas pelaksanaan pengadaan barang/jasa, diperoleh nilai $t_{\text {hitung }}$ sebesar 1.715 dan nilai $t_{\text {tabel }}$ sebesar 1,664. Nilai signifikansi sebesar $0,090<0,10$. Sesuai dengan penjelasan sebelumnya, maka dapat disimpulkan bahwa variabel integritas memiliki pengaruh positif dan signifikan terhadap kualitas peleksanaan pengadaan barang/jasa, atau $\mathrm{H}_{0}$ ditolak dan $\mathrm{Ha}$ diterima.

Pengaruh metode pemilihan penyedia barang/jasa terhadap kualitas pelaksanaan pengadaan barang/jasa, diperoleh nilai $t_{\text {hitung }}$ sebesar 4.474 dan nilai $t_{\text {tabel }}$ sebesar 1,664. Nilai signifikansi sebesar 0,000 . Sesuai dengan penjelasan sebelumnya, maka dapat disimpulkan bahwa variabel metode pemilihan penyedia barang/jasa memiliki pengaruh positif dan signifikan terhadap kualitas pelaksanaan pengadaan barang/jasa, atau $\mathrm{H}_{0}$ ditolak dan Ha diterima.

Uji koefisien determinasi dalam regresi linear berganda, untuk regresi dengan lebih dari dua variabel bebas digunakan adjusted $R^{2}$ sebagai koefisien determinasi. Berdasarkan hasil pengujian menunjukkan bahwa nilai $\mathrm{R}$ square $\left(\mathrm{R}^{2}\right)$ sebesar 0 , 281. Hal tersebut menjelaskan bahwa sebesar $28 \%$ dari seluruh variabel bebas $\left(\mathrm{X}_{1}, \mathrm{X}_{2}, \mathrm{X}_{3}, \mathrm{X}_{4}\right)$ yang diuji masih memiliki kontribusi yang rendah untuk mempengaruhi kualitas pelaksanaan pengadaan barang/jasa. Adapun sisanya sebesar $72 \%$ dari kualitas pelaksanaan pengadaan barang/jasa memungkinkan untuk dipengaruhi oleh variabel-variabel lain yang tidak dijelaskan pada penelitian ini.

\section{Pengaruh Harga Perkiraan Sendiri terhadap Kualitas Pelaksanaan Pengadaan Barang/jasa}

Hasil pengujian hipotesis pertama menunjukkan bahwa variabel harga perkiraan sendiri, $\mathrm{t}_{\text {hitung= }}$ $-1.869>\mathrm{t}_{\text {tabel }}=1,664$ sehingga harga perkiraan sendiri memiliki pengaruh negatif dan signifikan terhadap kualitas pelaksanaan pengadaan barang/jasa Pemerintah Provinsi Gorontalo. Nilai koefisien regresi harga perkiraan sendiri sebesar $-0,208$. Hal ini berarti bahwa semakin buruk penyusunan harga perkiraan sendiri maka kualitas pelaksanaan pengadaan barang/jasa akan menurun.

Sebagaimana yang tertuang dalam perpres nomor 54 tahun 2010 pasal 66 ayat 3 yaitu Nilai total HPS bersifat terbuka dan tidak rahasia, sehingga memungkinkan bagi penyedia barang/jasa dapat melakukan penawaran yang sesuai dan tidak menimbulkan kecurigaan terhadap penyelenggara pengadaan barang/jasa dan menciptakan persaingan yang sehat diantara penyedia barang/jasa.

Dalam penyusunan harga perkiraan sendiri Pejabat Pembuat Komitmen (PPK) bisa menggunakan jasa konsultan apabila diperlukan. Hal ini dilakukan agar kiranya dapat membantu untuk menciptakan pelaksanaan pengadaan yang efisien dan efektif. Meskipun HPS bukan menjadi dasar untuk menentukan besaran kerugian negara, akan tetapi dalam pemeriksaan HPS bisa diperhitungkan sebagai salah satu unsur dalam terealisasinya kualitas pelaksanaan pengadaan barang/jasa. Hasil penelitian ini didukung dengan penelitian Menezes, Pitchford dan Wait.(2003) menunjukkan bahwa pemerintah akan lebih cenderung memilih pemenang dengan harga terendah (memiliki kejelasan, spesifikasi tertentu, memenuhi persyaratan dan standar kualitas).

\section{Pengaruh Waktu Pelaksanaan Pengadaan Barang/jasa terhadap Kualitas Pelaksanaan Pengadaan Barang/jasa}

Hasil pengujian hipotesis kedua menunjukkan bahwa variabel waktu pelaksanaan pengadaan barang/jasa, $\mathrm{t}_{\text {hitung }}=1.756>\mathrm{t}_{\text {tabel }}=1,664$ sehingga waktu pelaksanaan pengadaan barang/jasa berpengaruh positif dan signifikan terhadap kualitas pelaksanaan pengadaan barang/jasa. Nilai koefisien regresi variabel waktu pelaksanaan pengadaan barang/jasa sebesar 0,176 . Hal ini dapat diartikan semakin baik waktu pelaksanaan pengadaan barang/jasa maka akan semakin baik pula kualitas pelaksanaan pengadaan barang/jasa di Pemerintah Provinsi Gorontalo.

Waktu Pelaksanaan pengadaan barang/jasa anggaran merupakan tahapan yang di lakukan dalam pengadaan barang/jasa K/L/D/I yang tertuang dalam Kerangka Acuan Kerja (KAK) di setiap $\mathrm{K} / \mathrm{L} / \mathrm{D} / \mathrm{I}$ yang kemuadian akan dikaji oleh PPK dan ULP untuk dapat menentukan jenis kontrak akan digunakan. Pengkajian itu tentunya untuk dapat mewujudkan prinsip dari efesiensi, sebagaimana yang tertuang dalam Perpres Nomor 54 Tahun 2010 tentang pengadaan barang/jasa pemerintah pasal 5.a yaitu Efisien, berarti Pengadaan Barang/Jasa harus diusahakan dengan menggunakan dana dan daya yang minimum untuk mencapai kualitas dan sasaran dalam waktu yang ditetapkan atau menggunakan dana yang telah ditetapkan untuk mencapai hasil dan sasaran dengan kualitas yang maksimum.

Penelitian Messah (2013) yang berjudul pengendalian waktu dan biaya pekerjaan konstruksi sebagai dampak dari perubahan desain, memberikan hasil bahwa Kinerja pekerjaan berjalan buruk karena tidak sesuai jadwal (terlambat) dan biayapun lebih tinggi dari nilai kontrak. 


\section{Pengaruh Integritas terhadap Kualitas Pelaksanaan Pengadaan Barang/jasa}

Hasil pengujian hipotesis ketiga menunjukkan bahwa variabel integritas, $t_{\text {hitung }}=1,715>t_{\text {tabel }}=$ 1,664 sehingga integritas berpengaruh positif dan signifikan terhadap kualitas pelaksanaan pengadaan barang/jasa. Nilai koefisien regresi variabel integritas sebesar 0,228 . Hal ini dapat diartikan bahwa jika integritas yang dimiliki oleh panitia barang/jasa baik maka kualitas pelaksanaan pengadaan barang/jasa akan semakin baik.

Untuk mendukung kualitas pelaksanaan pengadaan barang/jasa, integritas merupakan persyaratan pertama yang harus dimiliki oleh Pengguna Anggaran (PA), Kuasa Pengguna Anggaran (KPA) Pejabat Pembuat Komitmen (PPK), Pokja ULP, dan Pejabat pengadaan. Pakta Integritas merupakan surat pernyataan yang berisi tentang sikap dan tanggungjawab untuk dapat mencegah dan tidak melakukan perbuatan yang menjurus pada sikap kolusi, korupsi dan nepotisme. Sebagaimana dalam Perpres Nomor 54 Tahun 2010 pasal 1 angka 13 yang berbunyi pakta integritas adalah surat pernyataan yang berisi ikrar untuk mencegah dan tidak melakukan kolusi, korupsi, dan nepotisme dalam pengadaan barang dan jasa. Pakta integritas hanyalah dokumen yang tidak akan berfungsi untuk mewujudkan tata kelola pemerintah yang baik dan bersih (good governance and clean government) kalau tidak diimplementasikan dalam pelaksanaan pengadaan barang/jasa pemerintah oleh semua pihak yang terlibat dalam kegiatan pengadaan barang/jasa pemerintah (Ansari, 2016).

Penelitian yang dilakukan oleh Huslina (2015) yang berjudul pengaruh integritas aparatur, kompetensi aparatur, dan pemanfaatan teknologi informasi terhadap efektivitas sistem pencegahan fraud menunjukkan bahwa hasil integritas aparatur berpengaruh positif terhadap efektif sistem pencegahan fraud. Selain itu sama halnya dengan penelitian tentang integritas pejabat publik yang dilakuka oleh Hernandez dan Groot (2007), Siahaan (2009) memberikan bukti bahwa Integritas aparatur memiliki pengaruh terhadap efektifitas sistem pencegahan fraud.

\section{Pengaruh Metode Pemilihan Penyedia Barang/jasa terhadap Kualitas Pelaksanaan Pengadaan Barang/jasa}

Hasil pengujian hipotesis keempat menunjukkan bahwa variabel metode pemilihan penyedia barang/jasa, $t_{\text {hitung }}=4.474>t_{\text {tabel }}=1,664$ sehingga metode pemilihan penyedia barang/jasa berpengaruh positif dan signifikan terhadap kualitas pelaksanaan pengadaan barang/jasa. Nilai koefisien regresi variabel metode pemilihan penyedia barang/jasa sebesar 0,463 . Hal ini dapat diartikan bahwa jika metode pemilihan penyedia barang/jasa terlaksanan dengan baik maka kualitas pelaksanaan pengadaan barang/jasa akan semakin baik.

Metode pemilihan penyedia barang/jasa merupakan bentuk kegiatan yang ada pada pangadaan barang/jasa. Hal ini tertuang dalam perpres nomor 54 tahun 2010 tentang pengadaan barang/jasa pemerintah pada bagian ketiga pemilihan sistem pengadaan. Dalam sistem pengadaan barang/jasa terdapat beberpa metode yang dapat digunakan dalam pelaksanaan pengadaan barang/jasa. Seperti yang terdapat pada pasal 35 poin 1 yaitu ULP/Pejabat Pengadaan menyusun dan menetapkan metode pemilihan Penyedia Barang/Pekerjaan Konstruksi/Jasa Lainnya. Serangkaian kegiatan untuk menyediakan barang/jasa dengan cara menciptakan persaingan yang sehat di antara penyedia barang/jasa yang setara dan memenuhi syarat berdasarkan metode dan tata cara tertentu yang telah ditetapkan dan diikuti oleh pihak-pihak yang terkait secara taat azas sehingga terpilih penyedia terbaik (Wulfram, 2004). Hasil penelitian Thai (2001) yang mengungkapkan bahwa ketentuan dan prosedur pengadaan barang/jasa juga berpengaruh terhadap keberhasilan suatu sistem pengadaan barang/jasa pemerintah dalam mencapai tujuan yang telah ditetapkan.

\section{Kesimpulan Dan Saran}

Berdasarkan hasil penelitian, maka dapat disimpulkan bahwa harga perkiraan sendiri memiliki pengaruh negatif dan signifikan terhadap kualitas pelaksanaan pengadaan barang/jasa pada Pemerintah Provinsi Gorontalo, sedangkan waktu pelaksanaan pengadaan barang/jasa, integritas, dan metode pemilihan penyedia barang/jasa memiliki pengaruh positif dan signifikan terhadap kualitas pelaksanaan pengadaan barang/jasa pada Pemerintah Provinsi Gorontalo.

Saran untuk Pemerintah Provinsi Gorontalo dalam upaya miningkatkan kualitas pelaksanaan pengadaan barang/jasa diharapkan perlu untuk terus meningkatkan kemampuan teknis bagi para pejabat fungsional terkait pengadaan barang/jasa dengan cara melakukan pelatihan/sertifikasi pengadaan barang/jasa. Selain itu dalam pelaksanaan pengadaan barang/jasa perlu untuk selalu 
memperhatikan peraturan perundang-undangan yang berlaku, dan menciptakan lingkungan birokrasi yang baik dengan cara menjalin koordinasi yang baik antar pegawai khususnya dalam pegadaan barang/jasa.

\section{Daftar Pustaka}

Alfian. 2015. Pemetaan Jenis dan Resiko Kecurangan Dalam Audit Pengadaan Barang dan Jasa. Jurnal Pengadaan. ISSN:2089-2861. Vol.4, No.1.

Ansari, Muhammad Insa. 2016. Penerapan Pakta Integritas Pada Pengadaan Barang/Jasa Untuk Mewujudkan Tata Kelola Pemerintah Yang Bersih. Jurnal Ilmu Hukum Vol. 18, No. 3, Desember, 2016, hal 385-401.

Beth, Elodie. 2005. Main Findings of the Forum Workshop on "improving Transparency in Public Procurement". In OECD. Fighting Corruption and promoting Integrity in Public Procurement. Paris. OECD.

BPK RI., 2016. Ikhtisar Hasil Pemeriksaan Semester II. Jakarta

Ghozali. Imam. 2013. Aplikasi Analisis Multivariate Dengan Program SPSS Edisi Keempat. Semarang: Badan Penerbit Universitas Diponegoro.

Hehamahua, A. 2011. Pengadaan Barang dan Jasa, Korupsi dan Reformasi Birokrasi. http://www.lkpp.go.ig, diakses pada tanggal 12 Maret 2017.

Hernandez, J. R. dan T. Groot. 2007. Corporate Fraud: Preventive Controls Which Lower Corporate Fraud. Amsterdam Research Centre in Accounting.

Huslina, Hersi. 2015. Pengaruh Integritas Aparatur, Kompetensi Aparatur dan Pemanfaatan Teknologi Informasi Terhadap Efektivitas Sistem Pencegahan Fraud. Jurnal Magister Akuntansi. Pascasarjana Univ. Syiah Kuala. ISSN: 2302-0199. hal 55-64.

Jatiningtyas, N. dan Endang, K. 2011. Analisis Faktor-Faktor Yang Mempengurahi Fraud Pengadaan Barang/Jasa Pada Lingkungan Instansi Pemerintah Di Wilayah Semarang. Tesis, Universitas Diponegoro.

Larasati, D. 2011. Development of Contractor Quality Assurance System in Indonesia Construction Procurement, unpublished Doctor of Philosophy dissertation, Graduate School of Engineering, Kochi University of Technology, Kochi, Japan

Messah, Yunita Afliana. 2013. Pengendalian Waktu dan Biaya Pekerjaan Konstruksi Sebagai Dampak Dari Perubahan Desain (Studi Kasus Embung Irigasi Oenaem, Kecamatan Biboki Selatan Kabupaten Timor Tengah Utara). Jurnal Teknik Sipil Vol. II No. 2, September 2013.

Menezes, F. M., R. Pitchford, dan A. Wait. 2003. Tendering and Bidding for Access: A Regulator's Guide to Auctions. Australian Journal of Management, Vol 28, No 3, hal 345-370.

Ogunsanmi, O, E. 2013. Effects of Procurement Related Factors on Construction Project Performance In Nigeria. Ethiopian Journal of Environmental Studies and Management. Vol.6,No.2.

Pich, Michael T., Loch Christoph H Loch and Meyer de Arnoud. (2002). On Uncertainty, Ambiguity, and Complexity in Project Management. Informs. Management Science, Vol 48. No.8. hal 1008-1023.

Republik Indonesia. 2000. Keputusan Menteri Nomor 18 tahun 2000 tentang Pedoman Pelaksanaan Pengadaan Barang/Jasa Instansi Pemerintah.

Republik Indonesia. 2010. Peraturan Presiden Nomor 54 Tahun 2010 tentang Pengadaan Barang/Jasa Pemerintah.

Schlenker, B.R., Miller, M.L. \& Johnson, R.M, 2009. Moral Indentity, integrity and personal responsibility. In D. Narvaez \& D.K. Lapsey, Personality, identity and character. Cambridge: Cambridge University Press. hal 316-340.

Siahaan, OCH. 2009. Pengaruh Integritas, Obyektivitas, dan Kompetensi terhadap Efektivitas Audit Internal. Tesis-Abstrak. Program Pascasarjana Unifersitas Gajah Mada.

Sugiyono. 2013. Metode Penelitian Bisnis. Alfabeta. Bandung.

Setiaji, Bambang. 2004. Panduan Riset Dengan Pendekatan Kuantitatif. Surakarta. Program Pascasarjana UMS, 2004.

Thai, K. V. 2001. Public Procurement Re-examined. Journal of Public Procurement, Vol 1, No 1, hal 9-50.

True, N.F. 1988. Determining the Accuracy of a Cost Estimate. AACE Transaction, T.2.1 - T.2.10. 
Wulfram, Ervianto. 2004. Teori Aplikasi Manajemen Proyek Konstruksi. Edisi I, Yogyakarta: Penerbit Andi. 